\title{
Determinants of Internet Use and Internet Penetration in Eritrea: Evidences from the City of Asmara
}

\author{
Fitsum Ghebregiorgis ${ }^{1} \&$ Habteab Tekie Mhreteab ${ }^{2}$ \\ ${ }^{1}$ Department of Business Management and Marketing, College of Business and Economics, Eritrea \\ ${ }^{2}$ Department of Economics, College of Business and Economics, Eritrea \\ Correspondence: Fitsum Ghebregiorgis, College of Business and Economics, P.O. Box 3963, Asmara, Eritrea. Tel: \\ 291-716-1013. E-mail: fitadiam@gmail.com
}

Received: February 11, 2018; Accepted: March 8, 2018; Published: March 29, 2018

\begin{abstract}
This study is designed to determine the use of internet and internet penetration in the city of Asmara, Eritrea with a view to inform policy makers and societal stakeholders on the implications of user behavior for future Internet related options. Self-designed questionnaire was distributed to the districts of the city based on stratified sampling method. $300(86 \%)$ of the 350 distributed questionnaires were found useable on return. However, only $232(77 \%)$ respondents have acknowledged to have made use of the Internet in the last three months. The results show that there is a glaring difference between the genders; female being in the minority and generally the younger ones and young adults constituted the highest users; majority of users are single with senior secondary school certificate followed by college graduates as highest qualification. In addition, users prefer regular visit and shorter browsing hours and the reasons for Internet use follow the usual trend including e-mail, social networking, information searching and video/voice calling.
\end{abstract}

Keywords: Internet use, internet penetration, developing country, Eritrea

\section{Introduction}

The worldwide computer network dubbed as Internet has become the everyday word for different ages, sex, career, academic status etc. bringing the world together just like a global village. From its humble beginnings as a communications tool for use by scientists and academics, the Internet has now grown exponentially in terms of both size and usage. Accordingly, in the past few decades, the Internet technology has shaped and transformed the way people live, both personally and professionally.

Information and communication technology (ICT) without doubt has an important role to play in developing a nation. Some studies noted that ICT offers remarkable opportunities for the alleviation of poverty and employment generation as well as producing higher achievement among those who master it (Rao, 2004; Abdul et al., 2009). Production, transportation, finance, academia, professional services, and broadcasting are some examples of sectors that have been transformed by ICTs (Ramirez, 2001).

The Internet has been/is spreading rapidly throughout the world. This can be seen from the increase in the number of hosts (computers connected to the Internet) and Internet users in the world (International Telecommunication Union, 2014). The worldwide Internet penetration increased significantly from $6.5 \%$ to $51.70 \%$ over the period from 2000 to 2017 (Internet World Statista, 2017).

Nonetheless, the expansion of Internet is not fairly distributed throughout the world as $66 \%$ of the population (4 billion people) in developing countries was without Internet services and a remarkable case is the situation presented from Africa. Internet in Africa is limited by a lower penetration rate when compared to the rest of the world. For instance, Africa's penetration rate is only $31.2 \%$ as compared to North America's $88.10 \%$ (Internet World Statista, 2017).

It is evident that the gap in Internet use rates between developed countries and the African continent has tended to widen in recent years. Most users in developed nations have a broadband connection at home whereas online speeds experienced in Africa are still very slow and impede access to certain uses requiring large bandwidth (Wikipedia, 2017). All measurable parameters and overall available bandwidth all indicate that Africa is way behind the digital divide. 
Besides, Africa itself exhibits an inner digital divide, with most Internet activity and infrastructure being concentrated in very few African countries such as South Africa (54\%), Morocco (58.3\%), Egypt (39.9\%) as well as smaller economies like Mauritius and Seychelles with 54\% (Wikipedia, 2017). There are also other African countries such as Togo, Burundi and Eritrea who have much lower penetration rate with only $13 \%, 14 \%$ and $1.3 \%$ respectively (Internet World Statista, 2017).

Obstacles to the accessibility of Internet services in Africa include generally low levels of computer literacy in the population, poor infrastructures, and high costs of Internet services. Power availability is also scarce, with vast rural areas that are not connected to power grids as well as frequent black-outs in major urban areas such as Dar es Salaam (Wikipedia, 2017).

Many scholars have attempted to articulate the determining (decisive) factors behind Internet use to understand people's needs and behavior in this age of information technology. Ultimately fundamental human needs - such as communication, learning, entertainment, and sharing information and resources - were cited as key reasons for people's decisions to connect to the Internet. Literature indicates that different members of the global society use the Internet for different purposes and similarly the characteristics of these users also vary.

Many authors have revealed that socioeconomic and demographic characteristics are one of the main influences on the individual decision to use the Internet. For example, they demonstrate, among other things, that people who have not finished secondary school show less of an interest in using the Internet service (Hargittai and Shafer, 2006; Hargittai and Hinnant, 2008; Goldfarb and Prince, 2008).

Several studies have provided evidences on the influence of socio-economic and demographic characteristics on the use of the Internet. For instance, studies show that age influences the use of Internet and is found to be a major driver with the younger are more internet users than the older, although the purpose may vary (Chen et al., 2003; Oyelaran-Oyeyinka and Adeya, 2004; Penard, et al., 2013); sexual inequality in Internet access and usage with men are more internet users than women despite the fact that there are disparities among the continents (Ono and Zavodny, 2003; Chen et al., 2003; Oyelaran-Oyeyinka and Adeya, 2004; International Telecommunication Union, 2017; Anunobi, 2009; Penard, et al., 2013); that education is also one of the most dramatic differentiator in Internet use in that Internet use entails high level of education (Pénard et al., 2012; Penard, et al., 2013); and different people use the Internet for different purposes such as research, entertainment, social networking, e-commerce, games...etc (Savolainen and Kari, 2004; Olasina, 2006; AL-Hammasany, and Heshmati, 2011; Bankole et al., 2012); and the frequency of visits to the Internet and the length of time spent browsing is also different between developing and developed countries (Savolainen and Kari, 2004; Borzekowski, et al., 2006). Similarly, duration (how long people have been using the Internet) and place (whether they use at home or public places such cybercafé, public libraries, offices, etc) is also different among countries (Bankole et al., 2012; Penard, 2009). However, the introduction of smart mobile phones and the allowing possibility of accessing internet facilities with mobile phones in many African countries is changing nowadays the issue of venue.

It is imperative to fill this gap by identifying the characteristics of Internet users and penetration in the city of Asmara, Eritrea where the majority of the nation's Internet facilities are to be found. It is; therefore, the main purpose of this paper to answer questions such as who, why, what for, where etc., in relation to the Internet users in the city of Asmara. Similarly, we seek also to find out whether these factors are similar to those observed in studies conducted in other countries.

To the best of our knowledge, no studies have been conducted in Eritrea to closely identify and compare Internet use patterns and penetration rate at the individual level. It is the objective as well as the contribution of this paper to clearly provide insights on the factors that explain Internet use and the disparities in online usage among Internet users in the country.

\section{Research Methodology}

This is a descriptive survey which employed questionnaire to collect data from the Internet users in Asmara. The study is conducted based on the primary and secondary data collected from the city of Asmara in 2017. Primary data was collected from individual residents of the city using survey questionnaire. We distributed a total of 350 questionnaires and $300(85.6 \%)$ useable questionnaire were returned. Individuals were contacted based on a stratified random sample of residential addresses and were requested to give information related to the use of the Internet. Of the total 300 respondents, 232 individuals have acknowledged to have used the Internet in the last three months. The quantitative data gathered were collated, organized and analyzed with frequency tables, percentages and graphs. 


\section{Data Analysis}

The data collected are analyzed taking into account several factors such as age, gender, marital status, educational level and occupation of Internet users. In addition, users' frequency, reasons for use, purposes and the motive they want to achieve by using the Internet are also presented.

\section{Age and Sex of Users}

Results harvested through the stratified random sampling shows that out of two hundred thirty two (232) respondents sixty one percent (61\%) are males, while 39\% are females. It shows that there is still a big difference between males and females who use the Internet although one observes that females are catching up and there is a tendency of narrowing down of this gap.

Table 1 shows respondents' age and sex distribution and reveals that the age group (21-30) constitutes $56 \%$ of Internet users, followed by the age group ( 20 and below) which constitutes $20.6 \%$. Relating the age to sex of Internet users, more male children and male younger adults use Internet than their female counterparts. The result supports the former literal works which asserts that the male youth are the largest users of the Internet.

Table 1. Age and Gender of Users

\begin{tabular}{lllllll}
\hline & Age & & & & & \\
\cline { 2 - 7 } Male & Below 20 & $21-30$ & $31-40$ & $41-50$ & 50 and above & Total \\
& 22 & 76 & 25 & 9 & 9 & 141 \\
\multirow{4}{*}{ Female } & $(45.8)$ & $(58.5)$ & $(73.5)$ & $(81.8)$ & $(100)$ & $(60.8)$ \\
& 26 & 54 & 9 & 2 & 0 & 91 \\
& $(54.2)$ & $(41.5)$ & $(26.5)$ & $(18.2)$ & $(0)$ & $(39.2)$ \\
\hline Total & 48 & 130 & 34 & 11 & 9 & 232 \\
& $(100)$ & $(100)$ & $(100)$ & $(100)$ & $(100)$ & $(100)$ \\
\hline
\end{tabular}

\section{Marital Status and Educational Level}

Responses on marital status and educational attainment of Internet users are displayed in the following tables. A result on marital status reveals that majority of Internet users are single (72.4\%) as against (24.6\%) who were married. Table 2 below presents the results. Perhaps the result that it is the single ones who use more the Internet could be because they have less financial responsibility than married people and for this group the cost of using Internet is affordable.

Table 2. Marital Status of Respondents

\begin{tabular}{llll}
\hline & Frequency & Percent & Cumulative Percent \\
\hline Married & 57 & 24.6 & 24.6 \\
Divorced & 5 & 2.15 & 26.75 \\
Widowed & 2 & 0.86 & 27.60 \\
Single & 168 & 72.4 & 100.0 \\
Total & $\mathbf{2 3 2}$ & $\mathbf{1 0 0}$ & \\
\hline
\end{tabular}

The result (see Table 3) shows that high school graduates constitute the single largest group (31.9\%) followed by first degree graduates which constitute $26.72 \%$ of the Internet users. Contrary to some studies our result indicates that people with higher degrees (Masters and $\mathrm{PhD}$ ) are the minority among the Internet users showing that possibly there is no need of sophisticated higher education to use the Internet on the one hand, and on the other hand, the very limited number of people with Masters and PhDs in the country could also contributed to limited number of these group in the sample thus affecting the overall result. 
Table 3. Educational Level of Respondents

\begin{tabular}{llll}
\hline Educational Level & Frequency & Percent & Cumulative Percent \\
\hline Elementary School & 7 & 3.0 & 3.0 \\
Junior School & 9 & 3.9 & 6.9 \\
High School & 74 & 31.9 & 38.8 \\
Diploma & 58 & 25 & 63.8 \\
Bachelor Degree & 62 & 26.72 & 90.52 \\
Masters Degree & 7 & 3.0 & 93.5 \\
PhD & 1 & .43 & 94.0 \\
Other & 14 & 6.05 & 100.0 \\
Total & $\mathbf{2 3 2}$ & $\mathbf{1 0 0}$ & \\
\hline
\end{tabular}

\section{Gender and Education}

As can be seen from Table 4 in all the schools with the exception of Junior School (22.2\% to $77.8 \%$ ) the number of male Internet users is higher than the female users. However, contrary to their male parallels'majority of female internet users are high school graduates.

Table 4. Gender and Education

\begin{tabular}{llllllll}
\hline & Elementary & Junior & Secondary & B.A. Degree & M.A. Degree & PhD & Other \\
\hline Male & 5 & 2 & 41 & 36 & 7 & 1 & 5 \\
& $(71.4 \%)$ & $(22.2 \%)$ & $(55.4 \%)$ & $(62.1 \%)$ & $(100 \%)$ & $(100 \%)$ & $35.7 \%$ \\
Female & 2 & 7 & 33 & 22 & 0 & 0 & 9 \\
& $(28.6 \%)$ & $(77.8 \%)$ & $(44.6 \%)$ & $(37.9 \%)$ & $(0.0 \%)$ & $(0.00 \%)$ & $64.3 \%$ \\
Total & $\mathbf{7}$ & $\mathbf{9}$ & $\mathbf{7 4}$ & $\mathbf{5 8}$ & $\mathbf{7}$ & $\mathbf{1}$ & $\mathbf{1 4}$ \\
& $\mathbf{1 0 0 \%}$ & $\mathbf{1 0 0 \%}$ & $\mathbf{1 0 0 \%}$ & $\mathbf{1 0 0 \%}$ & $\mathbf{1 0 0 \%}$ & $\mathbf{1 0 0 \%}$ & $\mathbf{1 0 0 \%}$ \\
\hline
\end{tabular}

\section{Occupation of Users}

Regarding to employment situation of the respondents, the result indicate that students make up the majority (34.9\%) followed by government sector employees (33.2\%). On the other hand, home staying housewives are the least users of Internet with $0.86 \%$. It seems plausible that students use the internet for conducting assignment and researches more than other categories of respondents. Given that housewives are unemployed and more likely that they are not attending schools, it is not surprising to see that they are the least users of internet than others. Table 5 below shows the results.

Table 5. Occupation of Internet User

\begin{tabular}{llll}
\hline & Frequency & Percent & Cumulative Percent \\
\hline Student & 81 & 34.9 & 34.9 \\
Government Sector & 77 & 33.2 & 68.1 \\
Self-employed & 38 & 16.38 & 84.48 \\
Private Sector & 32 & 13.8 & 98.3 \\
Housewife & 2 & .86 & 99.1 \\
Other & 2 & .86 & 100.0 \\
\hline Total & $\mathbf{2 3 2}$ & $\mathbf{1 0 0}$ & \\
\hline
\end{tabular}

\section{Frequency and Duration of Internet Use}

Internet users' response on the frequency and duration of use is presented in Table 6. Pertaining to duration, the results show that majority of users $(50.8 \%)$ has been using the Internetfor more than three years. This is followed 
by those who have been browsing for the last two to three years (22.4\%). Thus, it can be said that majority of our respondents are not "newbies" ("newbies," was defined to mean people using the Internet one year or less). With regard to the frequency of use, the majority of users (38\%) browse the Internet only one time per week. The second largest group of browsers (23.3\%) uses the Internet twice per week.

Table 6. Frequency and Duration of Internet use

\begin{tabular}{|c|c|c|c|c|c|}
\hline \multicolumn{6}{|c|}{ Duration of Stay } \\
\hline Frequency & Less than 1 year & 1 to 2 years & 2 t o3 years & More than 3 years & Total \\
\hline $\begin{array}{l}1 \text { time per } \\
\text { week }\end{array}$ & $\begin{array}{l}13 \\
(59.1)\end{array}$ & $\begin{array}{l}20 \\
(50.0)\end{array}$ & $\begin{array}{l}23 \\
(44.2)\end{array}$ & $\begin{array}{l}32 \\
(27.1)\end{array}$ & $\begin{array}{l}88 \\
(37.9)\end{array}$ \\
\hline $\begin{array}{l}2 \text { times per } \\
\text { week }\end{array}$ & $\begin{array}{l}3 \\
(13.6)\end{array}$ & $\begin{array}{l}7 \\
(17.5)\end{array}$ & $\begin{array}{l}10 \\
(19.2)\end{array}$ & $\begin{array}{l}34 \\
(28.8)\end{array}$ & $\begin{array}{l}54 \\
(23.3)\end{array}$ \\
\hline $\begin{array}{l}3 \text { times per } \\
\text { week }\end{array}$ & $\begin{array}{l}1 \\
(4.5)\end{array}$ & $\begin{array}{l}6 \\
(15.0)\end{array}$ & $\begin{array}{l}8 \\
(15.4)\end{array}$ & $\begin{array}{l}26 \\
(22.0)\end{array}$ & $\begin{array}{l}41 \\
(17.7)\end{array}$ \\
\hline Daily & $\begin{array}{l}2 \\
(9.1)\end{array}$ & $\begin{array}{l}5 \\
(12.5)\end{array}$ & $\begin{array}{l}5 \\
(9.6)\end{array}$ & $\begin{array}{l}15 \\
(12.7)\end{array}$ & $\begin{array}{l}27 \\
(11.6)\end{array}$ \\
\hline Other & $\begin{array}{l}3 \\
(13.6) \\
\end{array}$ & $\begin{array}{l}2 \\
(5.0) \\
\end{array}$ & $\begin{array}{l}6 \\
(11.5) \\
\end{array}$ & $\begin{array}{l}11 \\
(9.3)\end{array}$ & $\begin{array}{l}22 \\
(9.5)\end{array}$ \\
\hline Total & $\begin{array}{l}22 \\
(100)\end{array}$ & $\begin{array}{l}40 \\
(100)\end{array}$ & $\begin{array}{l}52 \\
(100)\end{array}$ & $\begin{array}{l}118 \\
(100)\end{array}$ & $\begin{array}{l}232 \\
(100)\end{array}$ \\
\hline
\end{tabular}

\section{Frequency and Length of Brows Hours}

Internet users' response on the frequency and length of hours of use is presented in Table 7. From the table, it is evident that majority of them (52\%) use the Internetonly for one hour. The second largest group of users (32.75\%) browses the Internet only for two hours. This result perhaps is influenced by the price for internet use because relative to the standard of living of the population internet use price is expensive (that is, 1.25 US dollar per hour).

Table 7. Frequency and Length of Hours

\begin{tabular}{llllll}
\hline Frequency & Hours & & & & \\
\cline { 2 - 6 } One time per week & One hour & Two hours & Three hours & Other & Total \\
\cline { 2 - 6 } & 59 & 22 & 3 & 4 & 88 \\
Two times per week & $(48.8)$ & $(28.9)$ & $(14.3)$ & $(28.6)$ & $(37.9)$ \\
& 28 & 22 & 2 & 2 & 54 \\
Three times per week & $(23.1)$ & $(28.9)$ & $(9.5)$ & $(14.3)$ & $(23.3)$ \\
& 15 & 13 & 11 & 2 & 41 \\
Daily & $(12.4)$ & $(17.1)$ & $(52.4)$ & $(14.3)$ & $(17.7)$ \\
& 9 & 10 & 4 & 4 & 27 \\
Other & $(7.4)$ & $(13.2)$ & $(19.0)$ & $(28.6)$ & $(11.6)$ \\
& 10 & 9 & 1 & 2 & 22 \\
\hline Total & $(8.3)$ & $(11.8)$ & $(4.8)$ & $(14.3)$ & $(9.5)$ \\
& $\mathbf{1 2 1}$ & $\mathbf{7 6}$ & $\mathbf{2 1}$ & $\mathbf{1 4}$ & $\mathbf{2 3 2}$ \\
& $\mathbf{( 1 0 0 )}$ & $\mathbf{( 1 0 0 )}$ & $\mathbf{( 1 0 0 )}$ & $\mathbf{( 1 0 0 )}$ & $\mathbf{( 1 0 0 )}$ \\
\hline
\end{tabular}

\section{Gender and Duration}

Pertaining to the relationship between the gender of users and duration of time since they started browsing the Internet is shown in Table 8. The result indicates that in comparison to females males are veteran surfers. Out of $118(50.9 \%)$ respondents who have claimed to have been using the Internet for more than three years, the majority, that is, $84(71.2 \%)$ respondents are male users. Out of $55(23.7 \%)$ respondents who have asserted to have been using the Internet from two to three years the majority that is $28(53.8 \%)$ respondents are male users. Generally, we trace that males have been using the Internet for a longer period of time in comparison to females. 
Table 8 . Gender and duration

\begin{tabular}{llllll}
\hline & Less than a year & $\mathbf{1}$ to 2 years & $\mathbf{2}$ to 3 years & More than 3 years & Total \\
\hline Male & 9 & 20 & 28 & 84 & 141 \\
& $(40.9)$ & $(50.0)$ & $(53.8)$ & $(71.2)$ & $(60.8)$ \\
Female & 13 & 20 & 24 & 34 & 91 \\
& $(59.1)$ & $(50.0)$ & $(46.2)$ & $(28.8)$ & $(39.2)$ \\
\hline Total & $\mathbf{2 2}$ & $\mathbf{4 0}$ & $\mathbf{5 2}$ & $\mathbf{1 1 8}$ & $\mathbf{2 3 2}$ \\
& $(\mathbf{1 0 0})$ & $(\mathbf{1 0 0})$ & $\mathbf{( 1 0 0 )}$ & $\mathbf{( 1 0 0 )}$ & $(\mathbf{1 0 0})$ \\
\hline
\end{tabular}

\section{Money Spent per Week}

As Table 9 shows, the largest group of respondents (33.62\%) stated that the amount of money they spend is only 20 or less than that amount of Eritrean Nakfa (exchange rate is $\$ 1$ to 15 Nakfas) per week for browsing the Internet. The second largest group (25.86\%) of users spends between 21 and 40 Eritrean Nakfa per week for browsing purposes. As mentioned above price for using the Internet is expensive in Eritrea.

Table 9. Money Spend per week

\begin{tabular}{lllll}
\hline & $\begin{array}{l}\text { Money } \\
\text { (Nakfas) }\end{array}$ & Frequency & Percent & Cumulative Percent \\
\hline MONEY & $0-20$ & 78 & 33.62 & 33.6 \\
(Eritrean Nakfas) & $21-40$ & 60 & 25.86 & 59.5 \\
& $41-60$ & 39 & 16.81 & 76.3 \\
& $61-80$ & 10 & 4.31 & 80.6 \\
& $81-100$ & 16 & 6.90 & 87.5 \\
& Above 100 & 29 & 12.5 & 100.0 \\
\cline { 2 - 5 } & Total & $\mathbf{2 3 2}$ & $\mathbf{1 0 0}$ & \\
\hline
\end{tabular}

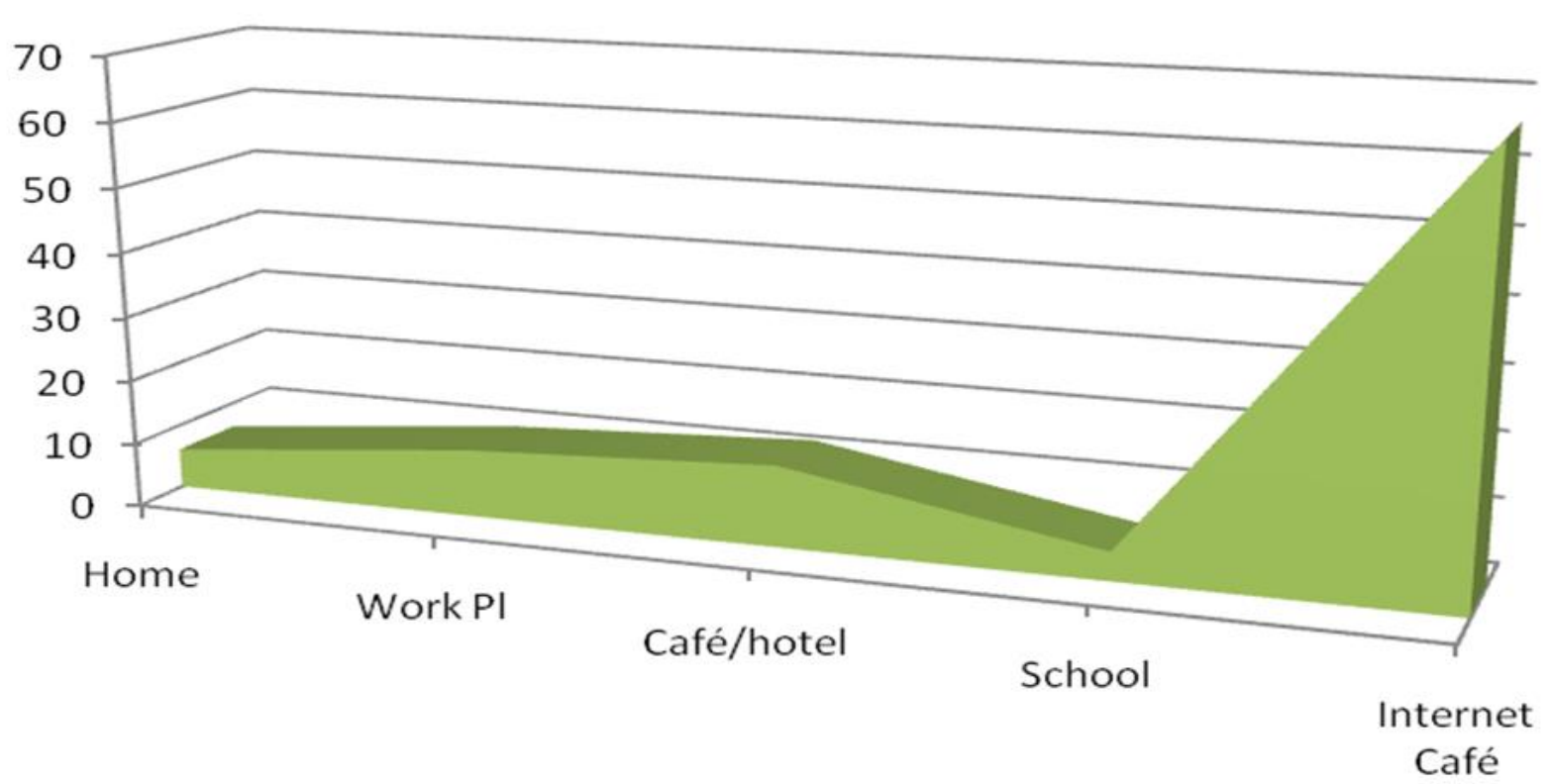

Figure 1. Place of Using Internet

\section{Place of Internet Browsing}

The results of our study concur with the findings of similar studies in other African countries that the majority $(66.21 \%)$ of respondents use Internet cafés in order to browse the Internet. The second weakest followers (12.61\%) are those who use café/hotel and restaurants for browsing purposes. Internet use in schools is very low as almost all of them do not have internet access with the exception of colleges who have limited internet connection. 
Undeniably, such kind of very limited access in schools can significantly affect the teaching and learning process in general, and the quality of education, in particular. This is mainly because students and teachers/instructors do not get up to date information and knowledge regarding new theories and research outcomes so that to be able to conduct research. Figure 1 below presents the result.

\section{Reasons for Using Internet}

Regarding to the main reasons for using the Internet, as can be seen from Figure 2 the largest group of respondents $(19.8 \%)$ browse the Internet for emailing reasons, followed by a group who use the Internet for social networking (16.31\%) and information searching (15.44\%). A significant amount of respondents also use Internet for voice/video calling as many Eritrean have close family members living abroad; downloading music/films; and uploading and downloading documents. Using Internet for trip reservation is almost non-existent due to poor infrastructure of Internet (very low bandwidth) and computer networking most organizations and companies in Eritrea even do not have websites. Using Internet for game playing is also very limited perhaps it could be that most Eritreans living in Asmara have smart phones, which they can easily get plenty of game applications.

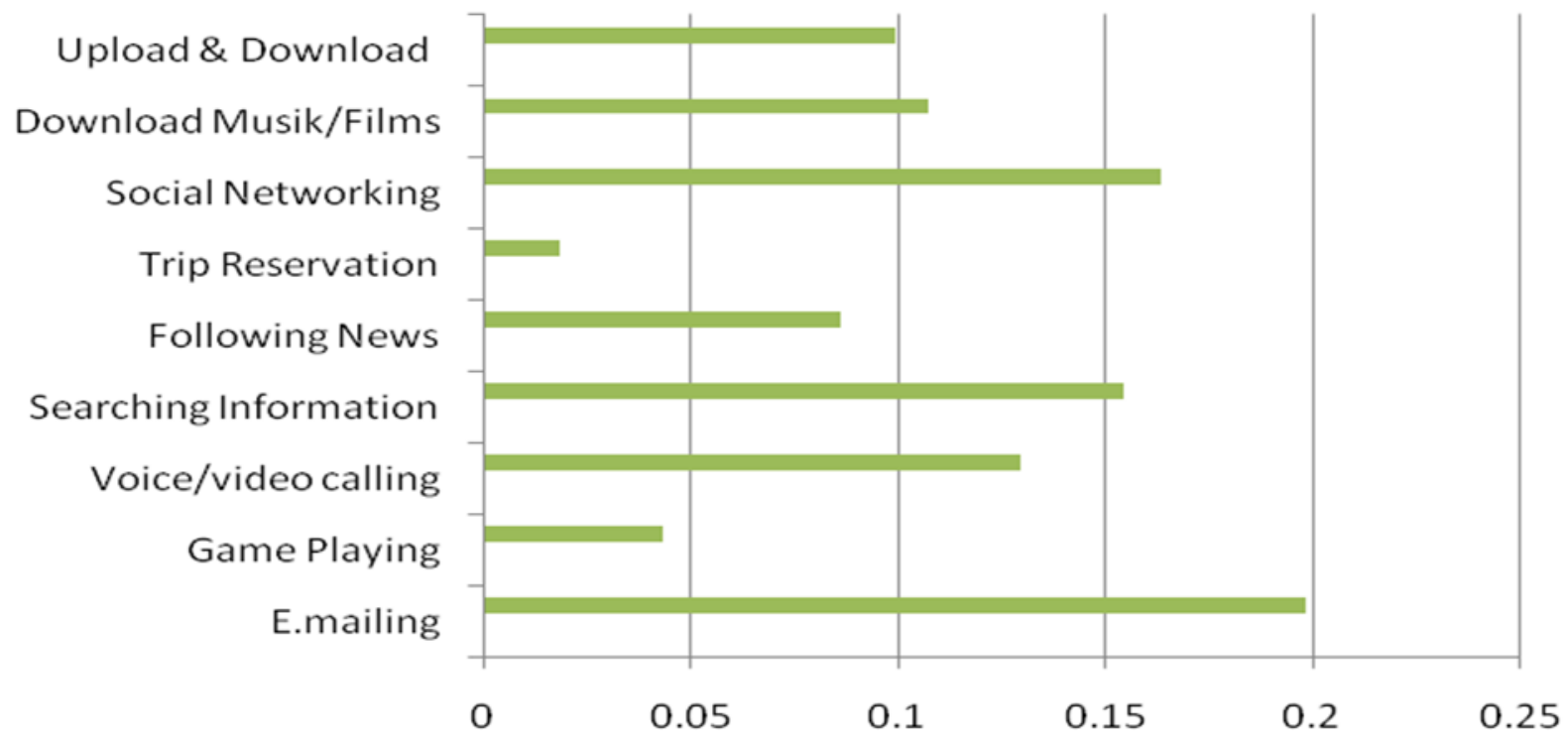

Percentage of Internet Users

Figure 2. Reasons for using the Internet

\section{Reasons for not using the Internet}

Developing countries have large segments of the population whose poverty and lack of literacy make Internet access unthinkable. In pertinence to this we have sixty eight (68) respondents out of the three hundred (300) who declared that they did not use the Internet in the last three months. The most important reasons people give for not browsing the Internet are lack of interesting content (31\%) in the web and lack of computer and browsing knowhow (26\%). In addition, shortage of English language is another reason as there are no websites in Eritrea with predominantly local language in which most of the citizens speak, read and write. The available ones which most people can access are the ones that are international are English. Even if Internet in Arabic language is available, a very insignificant number of people do read and write Arabic. There are also others who state Internet is expensive. 


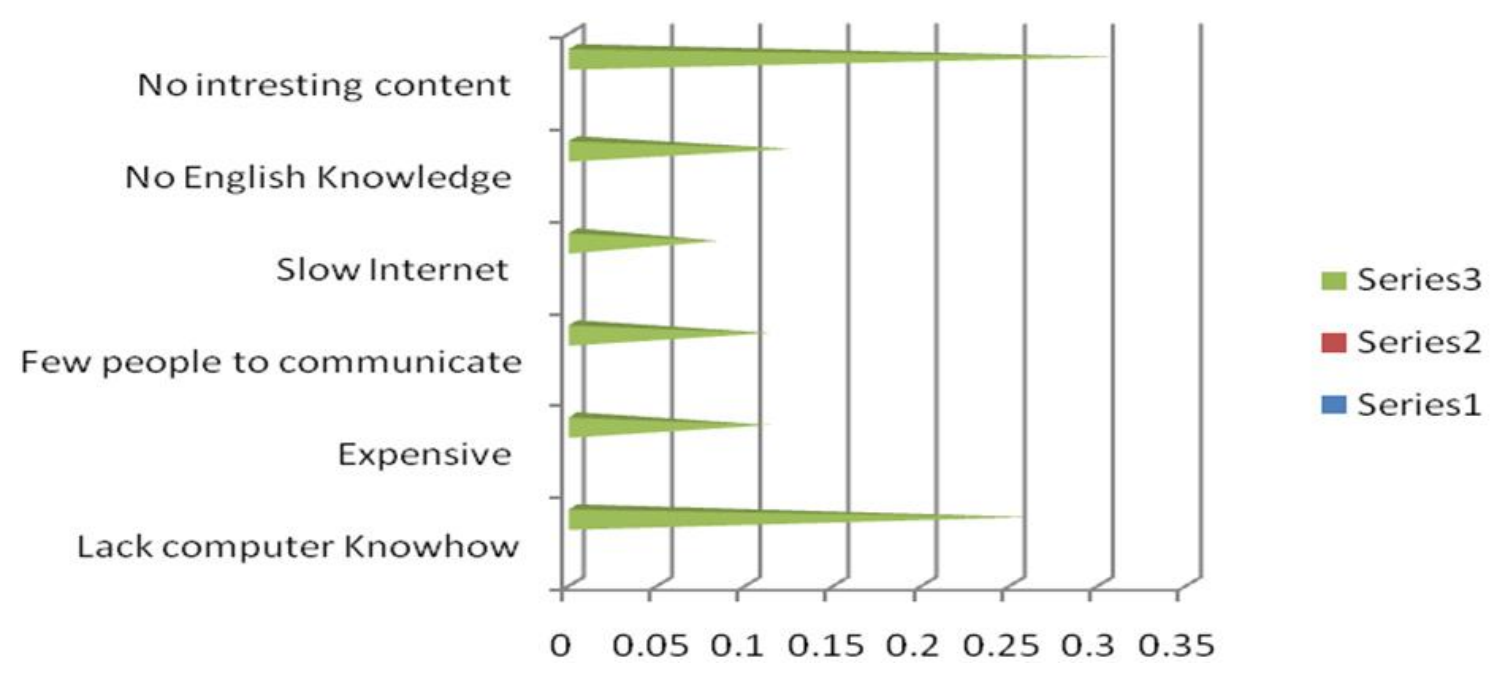

Figure 6. Reasons for not using the Internet

\section{Conclusions and Implications}

The primary goal of this paper has been to examine the profiles of Internet users in the city of Asmara, Eritrea in order to ascertain the ways in which they use the Internet and to enlighten policy makers and societal stakeholders on the implications of user behavior for future Internet related options. This is expected to answer questions such as who uses the Internet, for what purposes, under what circumstances, and how frequent, etc.

The data was collected in 2017 through stratified random sampling where the questionnaires were collected with face to face interviews, which increases the reliability of the sample. The results show that there is a glaring difference between the genders female being in the minority and generally users are found among the youth and young adults; majority of users are unmarried with senior secondary school certificate and college degree; users prefer regular visit and shorter browsing hours; reasons for Internet use follow the usual trend including e-mail, social networking, info searching and video/voice calling.

This study is the first of its kind for the country and it tried to critically evaluate the trend of Internet use and internet penetration in Asmara and provides immense scope for future studies on the impact of behavioral changes and changes in the life style of Eritrean people on Internet usage. Accordingly, further and broader research is needed, with regard to the usage of this technology and other ICTs, like mobile phones. This study also proves to be vital in development of future government policy for encouraging Internet use and investment in infrastructure. Hence, it aids in some useful regulations related to education and information technology development in Eritrea.

Despite the important benefits of information technology, digital policies are actually nonexistent or limited in many African countries (Gillwald et al., 2010). Bridging the above divides entails not only improving Internet access conditions (better infrastructure, high-speed service, etc.) and network coverage, training and introducing the populace with IT technologies, but also sound national digital policies. Besides, reducing the digital divide in the African continent requires taking into consideration technological, economic and political challenges.

In this endeavor, the Eritrean government should foster the process of making necessary investments and adjustments in the Internet infrastructure and systems in order to be able to meet the proper demands and needs of the citizens. Promotion of the use of the Internet in productive activities like e-government, education and business will certainly help in availability and effectiveness. In addition, parents have to create a mechanism of following their children's browsing behavior in order to check any anti-social practices; society should encourage young female adults to maximize their use.

\section{References}

Abdul, R. A., Norhasni, Z. A., Jamaludin, B., \& Pang, S.W. (2009), Computer Usage and Achievement Among Adults in Rural Area OF Malaysia, Journal of Social Sciences, 5(1), 1-8. https://doi.org/10.3844/jssp.2009.1.8

AL-Hammasany, H., \& Heshmati, A. (2011). Determinants of Internet Use in Iraq, International Journal of Communication, 5(2011). 
Anunobi, C. V., \& Mbagwu, F. C. (2009). Determinants of Internet Use in Imo State, Nigeria, Educational Research and Review, 4(9), 436-442. Retrieved from http://www.academicjournals.org/err, ISSN 1990-3839.

Bankole, O. M., \& Oludayo, B. S. (2012). Internet Use Among Undergraduate Students of Olabisi Onabanjo University, Ago Iwoye, Nigeria, Library Philosophy and Practice (e-journal), Retrieved from http://digitalcommons.unl.edu/libphilprac/812

Borzekowski, D. L. G., Fobil, J. N., \& Asante, K. O. (2006). Online Access by Adolescents in Accra: Ghanaian Teens' Use of the Internet for Health Information, Developmental Psychology, 42(3), 450-458. https://doi.org/10.1037/0012-1649.42.3.450

Chen, W., \& Wellman, B. (2003). The Global Digital Divide- Within and Between Countries, IT and Society, 1(7), 39-45

Gillwald, A., Milek, A., \& Stork, C. (2010). Towards Evidence-based ICT Policy and Regulation Gender Assessment of ICT Access and Usage in Africa, Research ICT Africa, Working Paper1, Policy Paper 5.

Goldfarb, A., \& Prince, J. (2008), Internet Adoption and Usage Patterns are Different: Implications for the Digital Divide, Information Economics and Policy, 20, 2-15. https://doi.org/10.1016/j.infoecopol.2007.05.001

Hargittai, E., \& Hinnant, E. (2008). Digital Inequality: Differences in Young Adults' Use of the Internet, Communication Research, 35(5), 602-621. https://doi.org/10.1177/0093650208321782

Hargittai, E., \& Shafer, S. (2006). Differences in Actual and Perceived Skills: The Role of Gender. Social Science Quarterly, 87(2), 432-448. https://doi.org/10.1111/j.1540-6237.2006.00389.x

International Telecommunications Union (ITU) (2014), Measuring the Information Society, Geneva.

Olasina, G. (2006). A User Requirement Analysis of Internet Resources by Clients' at Cyber cafes in Ibadan, Information Technology, 3, 30-39.

Ono, H., \& Zavodny, M. (2003). Gender and the Internet, SSE/EFI, Working Paper Series, Economics and Finance, No. 495.

Oyelaran-Oyeyinka, B., \& Adeya, C. N. (2004). Dynamics of Adoption and Usage of ICTs in African Universities: a Study of Kenya and Nigeria, Technovation, 24(10), 841-851. https://doi.org/10.1016/S01664972(02)00170-0

Penard T., \& Poussing, N. (2009). Internet Use and Social Capital: The Strength of Virtual Ties, Journal of Economic Issues, XLIV(3), 568-594.

Penard T., Poussing, N. B., Mukoko, G. B., \& Tamokwe, G. B. (2013). Internet Adoption and Usage Evidence from Cameroon Patterns in Africa, CEPS INSTEAD, Working Paper No 2013.

Penard, T., Poussing, N., Ella, P. N., \& Yebe, G. Z. (2012). Comparing the Determinants of Internet and Cell Phone Use in Africa: Evidence from Gabon, working paper, WP 2012-17, CNRS.

Ramirez, R. (2001). A Model for Rural and Remote Information and Communication Technologies: A Canadian Exploration. Telecommunication Policy, 25, 315-330. https://doi.org/10.1016/S0308-5961(01)00007-6

Rao S .S. (2004). Role of ICTs in India's Rural Community Information Systems, Journal of Information, 6(4), 261-269.

Savolainen, R., \& Kari, J. (2004). Placing the Internet in Information Source Horizons, a Sudy of Information Seeking by Internet Users in the Content of Self-Development, Libri Info. Sci. Res., 26, 415-433. https://doi.org/10.1016/j.lisr.2004.04.004

Statista. (2017). Multiple Statistical Data. Retrieved February 17, 2017, from http://www.statista.com

Wikipedia. (2017). List of African countries by GDP (nominal). Retrieved May 10, 2017, from http://en.wikipedia.org/wiki/List_of_African_countries_by_GDP_\%28nominal\%29

\section{Copyrights}

Copyright for this article is retained by the author(s), with first publication rights granted to the journal.

This is an open-access article distributed under the terms and conditions of the Creative Commons Attribution license (http://creativecommons.org/licenses/by/4.0/). 